\title{
Brunelleschi's Mirror, Perspectival Drawing and the Artful Prevention of Crime
}

\author{
A paper presented at the Art Crime Symposium, City Gallery Wellington Te \\ Whare Toi, Wellington, New Zealand, 29 May 2021
}

Dr Jonathan Barrett*

\begin{abstract}
Filippo Brunelleschi (1377-1446), a Florentine architect and Renaissance polymath, not only invented a mirror that allowed artists and draughtspersons to capture linear perspective, he was also the first beneficiary of a modern patent. Governments grant patents as time-limited, monopoly exploitation rights over inventions in exchange for full disclosure of the details of the invention. On the expiry of the monopoly, anyone can use and develop the invention. Perspectival drawings have been used for centuries both to prove and disclose inventions.

Patents are items of personal property but patent infringement is not technically theft. However, appropriating trade secrets that could lead to registration of a patent does constitute theft under the Crimes Act 1961.

This presentation flips the symposium theme of preventing art crime to consider how art may prevent certain crimes. The presentation considers Brunelleschi's mirror and the role of linear perspective in permitting the construction of drawings that plausibly represent threedimensional objects. These drawings are instrumental in proving inventiveness for patent registration purposes, and therefore the creation of property rights. They also constitute evidence that can contribute to preventing theft of trade secrets. Furthermore, they can be instrumental in proving infringement of copyright, registered designs or trade marks.
\end{abstract}

\section{Introduction}

We naturally see the world around us in linear perspective so that we perceive threedimensional objects in the round, rather than the flat. Despite Euclid (mid- $4^{\text {th }}$ century BCE) explaining the geometry of linear perspective in terms of a central vanishing point, ${ }^{1}$ it appears that people, across time and cultures, have rarely been concerned with replicating roundness in pictorial art. According to Samuel Edgerton:

\footnotetext{
* Associate Professor in Commercial Law and Taxation, Wellington School of Business and Government, Victoria University of Wellington Te Herenga Waka, Wellington New Zealand. This paper is a work in progress. Please do not cite without the author's permission.

$1 \quad$ Paul Calter Squaring the Circle: Geometry in Art \& Architecture "Brunelleschi's Peepshow \& The Origins of Perspective" < www.dartmouth.edu>.
} 
... even though we see "vanishing point" perspective in phenomenal nature, the notion of rendering it in pictures is not inherent. Human beings generally, even those born with socalled artistic talent, are never automatically inclined to draw images in the same way we perceive them perspectively - that is according to the geometric-optical laws of vision. ${ }^{2}$

\section{Edgerton further observes:}

No matter how obvious the optical illusion of perspective convergence and its generally taken-for-granted assumption in the Western-influenced world as being the trademark of pictorial "realism," it has rarely, and almost never outside this Western-influenced world, been of concern to artists before the Italian Renaissance. Most non-Western artists, and even Western artists during the early Middle-Ages, tended to render objects in 'divergent perspective."3

Indeed, it is possible that divergent perspective is the natural way to portray round objects in two dimensions, and that linear perspective needs to be learned as an artistic artifice or an art in itself. ${ }^{4}$ Thus, for Michael Clarke, "perspective" is "[t]he art of depicting solid objects on a two-dimensional or shallow surface so as to give the right impression of their height, width, depth, and position in relation to each other." 5

Although Ambrogio Lorenzetti's The Presentation at the Temple (1342) anticipated the artistic style of linear perspective, ${ }^{6}$ according to Clarke, linear perspective "was invented by Filippo Brunelleschi". ${ }^{7}$ Brunelleschi "developed a mirror device to project linear perspective as an

2 Samuel Edgerton The Mirror, the Window and the Telescope: How Renaissance Linear Perspective Changed Our Vision of the Universe (Cornell University Press, Ithaca (NY), 2009) at 2-3.

3 Edgerton, above n 2, at 3.

4 See Ian P Howard and Robert S Allison "Drawing with divergent perspective, ancient and modern" (2011) 40 Perception 1017.

5 Michael Clarke Oxford Concise Dictionary of Art Terms (2 $2^{\text {nd }}$ edn, Oxford University Press, Oxford, 2009) at 188.

6 According to the Head for Art blog, "linear perspective uses real or suggested lines (orthogonals) converging on the horizon line or at eye level. The place where the orthogonals meet is called the vanishing point”. See "Linear perspective” Head for Art (1 July 2016) <http://headforart.com>.

Clarke, above n 5, at 188 (emphasis added). Brunelleschi did not invent linear perspective - that is a natural phenomenon; rather his mirror was a device that revealed or enabled replication of that natural phenomenon. Patents cannot be claimed for something that occurs in nature. This is why computer 
artistic technique in the panels which he painted for the doors of the Florence Baptistry". ${ }^{8}$ Creation of this instrument was not the incrementalism of devising a better mousetrap, ${ }^{9}$ according to Giulio Argan and Nesca Robb:

The formulation of a common law for nature and for artistic form lies in perspective: which may in general terms, be defined as the method or mental procedure for the determination of value. In the writers of the Quattrocento ... we see clearly the belief that perspective is not simply a rule of optics which may also be applied to artistic expression but a procedure peculiar to art, which in art has its single and logical end. Perspective is art itself in its totality: no relation is possible between the human spirit and reality ... unless we assume the conception of nature. ${ }^{10}$

In short, the adoption of perspectival drawing revolutionised Western art. ${ }^{11}$

programs, which are based on naturally occurring algorithms, may be copyright-protected as literary works but are not capable of patent registration.

See also Heinrich Klotz Filippo Brunelleschi: The Early Works and the Medieval Tradition (Hugh Keith tr Academy Editions 1990) at 65, cited by Michael Blakeney "Patentability and fine art" in Jani McCutcheon and Fiona McGaughey (eds) Research Handbook on Art and Law (Edward Elgar, Cheltenham, 2020) 114 at 115.

Brunelleschi's mirror device is still used in studios today. On David Hockney's controversial claims that Renaissance artists used versions of the camera obscura to project images on to a canvas, see Duncan Graham-Rowe “Hockney 'was wrong' over art copying claims” New Scientist (15 January 2005).

Blakeney, above n 7, at 115

The example of a better mousetrap, which commonly features in patents discourse, is often, if perhaps erroneously, attributed to Ralph Waldo Emerson. See Jack Hope “A Better Mousetrap” American Heritage (October 1996) <www.americanheritage.com>.

Giulio Carlo Argan and Nesca A Robb "The Architecture of Brunelleschi and the Origins of Perspective Theory in the Fifteenth Century" (1946) 9 Journal of the Warburg and Courtauld Institutes 96 at 97 . The authors exclude Cennino Cennini and Lorenzo Ghiberti from the celebration of perspective. See ibid. Giorgio Visari also lampooned Paolo Uccello's obsession with perspective. See Clarke, above n 5, at $188-9$.

It is debatable whether Brunelleschi discovered or re-discovered techniques of drawing in linear perspective that were used by the ancient Greeks and Romans but forgotten after the fall of Rome. For a discussion, see Jocelyn Penny Small "Circling Round Vitruvius, Linear Perspective, and the Design of Roman Wall Painting” (2019) 8(3) Arts 118; https://doi.org/10.3390/arts8030118. 
Beyond painting, perspectival drawing allowed the portrayal of things that previously could not be plausibly communicated without depth of vision. ${ }^{12}$ The ability to employ linear perspective also had wide scale and long-lasting utilitarian benefits, notably in architectural drawing and, later, to depict inventions, when proving patents.

This paper is about the role of drawings that employ linear perspective in establishing and thereby protecting property rights against appropriation. The paper is structured as follows: part 2 sketches patents and other relevant intellectual property rights. Patents are personal property rights that are contingent on inventors being able to prove novelty and usefulness. Perspectival drawings are instrumental in this probative exercise. Part 3 sets out the requirements for patent drawings under New Zealand's current patents statute, the Patents Act 2013. Part 4 presents an argument that the specialist artistic practice of patent illustration, derived ultimately from Brunelleschi, is an artful means of preventing theft. Conclusions are then drawn.

\section{Patents and other intellectual property}

This part of the paper considers the nature of patents and related matters.

\subsection{What is a patent?}

12 Albrecht Dürer's Rhinoceros (1515), which was constructed as a cheap woodcut to enable maximal reproduction, is one of the most remarkable perspectival drawings of fauna. See Skye Sherwin “Albrecht Dürer's The Rhinoceros: the most influential animal picture ever?" The Guardian (online ed, London, 11 November 2016). A Wikipedia entry on Rhinoceros includes a contemporaneous sketch by Giovanni Giacomo Penni, crudely drawn in divergent perspective, of the actual creature.

Dürer was not only a pioneer artist, he was one of the first and most aggressive asserters of intellectual property rights in his works, including the following warning, issued in 1511 "in the colophon to an edition of an engraving series called Life of the Virgin":

Hold! You crafty ones, strangers to work, and pilferers of other men's brains. Think not rashly to lay your thievish hands upon my works. Beware! Know you not that I have a grant from the most glorious Emperor Maximillian, that not one throughout the imperial dominion shall be allowed to print or sell fictitious imitations of these engravings? Listen! And bear in mind that if you do so, through spite or through covetousness, not only will your goods be confiscated, but your bodies also placed in mortal danger.

See Noah Charney The Art of Forgery: The Minds, Motives and Methods of Master Forgers (Phaidon, London, 2015) at 11. 
Government may issue letters patent granting exclusive exploitation rights in respect of a novel invention that has an industrial use. ${ }^{13}$ To obtain a patent, technical information about the invention must be disclosed to the public in a patent application. ${ }^{14}$ The two key features of a patent are, first, the time-limited monopoly right and, second, the requirement to disclose details to others who may freely adopt and use the invention on the expiry of the monopoly. Both features of a patent require pictorial evidence.

\subsection{A nutshell history of patents}

Brunelleschi was a Florentine polymath. ${ }^{15}$ According to Plinio Innocenzi

Brunelleschi was ... more than just an architect and engineer. He was one of the best examples of a Renaissance man, with wide interests in many fields, similar to Leonardo and Francesco di Giorgio. In addition to architecture, he dedicated his time to a variety of activities such as studies of perspective, machines (not only for construction but also for theatrical representations), mechanics, and more fundamental studies in disciplines such as mathematics, astronomy, and hydraulics. ${ }^{16}$

\section{In Innocenzi’s opinion}

The construction of the Cupola of the cathedral in Florence (Cattedrale di Santa Maria del Fiore) by the Florentine architect Filippo Brunelleschi (1377-1446) represents one of those influencing events that are capable of affecting the course of history-in this case the

13 "What is a patent?" World Intellectual Property Organization <www.wipo.int>.

In terms of section 14 of the Patents Act 2103:

An invention is a patentable invention if the invention, so far as claimed in a claim,-

(a) is a manner of manufacture within the meaning of section 6 of the Statute of Monopolies; and

(b) when compared with the prior art base-

(i) is novel; and

(ii) involves an inventive step; and

(c) is useful; and

(d) is not excluded from being a patentable invention under section 15 or 16 .

Edgerton, above n 2, at 5 describes Brunelleschi as a "sculptor, engineer, architect, and all-around artisanimpresario".

Plinio Innocenzi The Innovators Behind Leonardo: The True Story of the Scientific and Technological Renaissance (Springer, Cham, 2019) at 43. 
history of art and technology. The Cupola is not only one of the greatest masterworks of Renaissance architecture but also marks the beginning of a new era beyond the known frontiers of traditional knowledge" ${ }^{17}$

It is generally accepted that, in 1421, Brunelleschi became the first beneficiary of a stateconferred monopoly right to exploit an invention.

The patent was issued for his barge-crane system, Il Badalone (the Monster), which was designed to ship and transport marble from the Carrara mountains along the Arno. ${ }^{18}$ The text of Brunelleschi's patent for Il Badalone provided: ${ }^{19}$

Considering that the admirable Filippo Brunelleschi, a man of the most perspicacious intellect, industry, and invention, citizen of Florence, has invented some machine or kind of ship, by means of which he thinks he can easily, at any time, bring in any merchandise and load on the river Arno and on any other river or water, for less money than usual, and with several other benefits to merchants and others, and that he refuses to make such machine available to the public, in order that the fruit of his genius and skill may not be reaped by another without his will and consent; and that, if he enjoyed some prerogative concerning this, he would open up what he is hiding and would disclose it to all;

And desiring that this matter, so withheld and hidden without fruit, shall be brought to light to be of profit to both said Filippo and our whole country and others, and that some privilege be created for said Filippo as hereinafter described, so that he may be animated more fervently to even higher pursuits and stimulated to more subtle investigations, they deliberated on 19 June 1421;

That no person alive, wherever born and of whatever status, dignity, quality, and grade, shall dare or presume, within three years next following from the day when the present provision has been approved in the Council of Florence, to commit any of the following acts on the river Arno, any other river, stagnant water, swamp, or water running or existing in the territory of Florence: to have, hold, or use in any manner, be it newly invented or made new in form, a machine or ship or other instrument designed to import or ship or transport on water any merchandise or any things or goods, except such ship or machine or instrument as they may have used until now for similar operations, or to ship or

17 Innocenzi, above n 16 , at abstract.

See, for example, L Sprague de Camp “An Early Patent-Law Proposal?” (1964) 5(3) Technology and Culture 377 . 
transport, or to have shipped or transported, any merchandise or goods on ships, machines, or instruments for water transport other than such as were familiar and usual until now, and further that any such new or newly shaped machine, etc. shall be burned;

This conferral of the monopoly privilege represents a calculation on the part of the Florentine government that Brunelleschi's invention would satisfy its requirements with regards to shipping marble for three years, to the extent that it is prepared to destroy anything that copies it during the exclusive exploitation period. In the event, Il Badalone sank on its maiden voyage. According to Ikechi Mgbeoji

Nothing is recorded about the details of the failure of "Badalone". No historian is certain as to whether the sinking or loss of the "Badalone" was a result of a flaw in the design or of human error or the malevolence of nature. What is certain is that the "Badalone" sank and that Brunelleschi lost ten years salary and a third of his entire wealth. For a long time thereafter, Florence stopped issuing patents..$^{20}$

In 1474, the Venetian Senate established the first general patent law that articulated the concept of intellectual property and recognised the importance of protecting inventors' rights. ${ }^{21}$ In England, section 6 of the Statute of Monopolies 1624 (21 Jac 1 c 3) provided that monopolies should only be granted for novel and useful inventions, and for a period of 14 years. ${ }^{22}$ This Act remained on the statute books for more than two centuries and informed the United States' first Patents Act in 1790. ${ }^{23}$ Indeed, the Patents Act 2013, like the Patents Act 1860 - the first domestic New Zealand legislation on the subject - continues to refer to section 6 of the Statute of Monopolies. ${ }^{24}$ Patent protection was patchy before the Paris Convention for the Protection

$20 \quad$ Ikechi Mgbeoji "The Juridical Origins of the International Patent System: Towards a Historiography of the Role of Patents in Industrialization" (2003) 5(2) Journal of the History of International Law 403 at 412-3 (footnotes omitted).

Ted Sichelman and Sean O'Connor "Patents as Promoters of Competition: The Guild Origins of Patent Law in the Venetian Republic" (2012) 49 San Diego Law Review 1267.

See "Statute of Monopolies 1623" legislation.gov.uk <www.legislation.gov.uk>.

The United States Constitution of 1787 specifically protected "science and the useful arts". Article I, section 8, clause 8 provides: "[The Congress shall have power] "To promote the progress of science and useful arts, by securing for limited times to authors and inventors the exclusive right to their respective writings and discoveries."

Patents Act 2013, s 14(a). 
of Industrial Property (1883); the Netherlands, for example, had no patent protection law between 1869 and $1910 . .^{25}$

\subsection{Mechanical Jurisprudence}

Alain Pottage and Brad Sherman note that three-dimensional models became popular in the United States in the nineteenth century to prove inventiveness because of perceived deficiencies in drawings plausibly conveying what an invention would look like in practice. ${ }^{26}$ This is no longer the case. According to the United States Patents and Trademarks Office (USPTO):

Models or exhibits are not required in most patent applications since the description of the invention in the specification and the drawings must be sufficiently full, clear, and complete and capable of being understood to disclose the invention without the aid of a model. $^{27}$

\subsection{Artworks and intellectual property rights}

Generally, visual artworks may qualify for copyright protection as original artistic works. ${ }^{28}$ No requirement exists for a graphic work, photograph, sculpture, collage, or model to manifest to artistic quality, whereas as a work of architecture or a work of artistic craftsmanship must. ${ }^{29}$

25 Stef van Gompel "Patent Abolition: A Real-Life Historical Case Study" (2019) 34(4) American University International Law Review 887. A consequence of the hiatus in patent protection in the Netherlands was the establishment and growth of the industrial giant Phillips which was able to appropriate Thomas Edison and Joseph Swan's light bulbs with impunity. See Antony Anderson "Review: Bright lights in the Netherlands / Review of 'The History of NV Philips' Gloeilampenfabriken; The Origin of the Dutch Incandescent Lamp Industry (Vol 1 and Vol 2)' by A. Heerding” NewScientist (11 November 1989) <https://institutions.newscientist.com>.

Alain Pottage and Brad Sherman Figures of Invention: A History of Modern Patent Law (Oxford University Press, Oxford, 2010)

"General information concerning patents" (2021) USPTO < www.uspto.gov>.

Copyright Act 1994, s 14.

Copyright Act 1994, s 2 definition of "artistic work". 
Occasionally, artworks may be registered as trade marks, ${ }^{30}$ and they may, in theory at least, qualify for patent registration. ${ }^{31}$

\subsection{The flat and the round}

In terms of copyright doctrine, a flat object may be copied in the round, and vice versa. For example, a tableau vivant may constitute a copy of a cartoon, ${ }^{32}$ even though a tableau vivant is not a copyright protected work. ${ }^{33}$ Likewise, a photograph of a sculpture may infringe copyright in the three-dimensional object, ${ }^{34}$ and vice versa. ${ }^{35}$ In an industrial context, if a rival copies, say, a three-dimensional glue dispenser, they also infringe any copyright in the twodimensional blueprints precursory to manufacture of the object, even if they have never had sight of the drawings. ${ }^{36}$ However, the Copyright Act restricts protection of artistic works that have been industrially applied ${ }^{37}$ to 16 years $^{38}$ (25 years in the case of a work of artistic craftsmanship $^{39}$ ).

\section{Drawings and patents}

30

For a discussion, see Full Colour Black Limited v Pest Control Office Limited (Decision on Cancellation No 33843 C, 14 September 2020). See generally, Michael Blakeney "Patentability and fine art" in Jani McCutcheon and Fiona McGaughey (eds) Research Handbook on Art and Law (Edward Elgar, Cheltenham, 2020) at 114.

See Simon Stokes, Art and Copyright (2nd edn, Hart, Oxford, 2012) at 23 n 60.

Kevin Garnett, Gillian Davies and Gwilym Harbottle Copinger and Skone James on Copyright (16th edn, Sweet \& Maxwell, London, 2011) at para 3-30 and 3-35.

On photographs of public statuary in the public view, see Jonathan Barrett "Time to look again? Copyright and Freedom of Panorama” (2017) Victoria University of Wellington Law Review 261.

See Rogers v Koons 960 F 2d 301 (2d Circ).

See Henkel KGaA v Holdfast New Zealand Ltd [2006] NZSC 102.

On the meaning of "industrially applied", see Copyright Act, s 75(4).

Copyright Act, s 75(1)(d).

Copyright Act, s 75(1)(c). For a discussion of the contentious issue of what constitutes a work of artistic craftsmanship, see Jonathan Barrett and Vladimir Samoylov "Copyright-protected works of artistic craftsmanship: Some comparative observations” (2021) 43 EIPR 104. 
Regulations prescribe the compliance requirements for patent applications. ${ }^{40}$ These include:

(a) each element of each drawing must be in proper proportion to every other element of the drawing, except where the use of a different proportion is necessary to ensure that the drawing is clear:

(b) the scale of drawings must be sufficiently large to show the invention clearly, and only so much of the product may appear as effects this purpose:

(c) the scale of drawings and their distinctness must be such that they are capable of being reproduced with a linear reduction in size to two-thirds of their original size in a way that would enable all details to be distinguished without difficulty:

(d) if the scale is given, it must be represented graphically and not denoted by words, and no dimensions may be marked on the drawings ...

\section{Drawings and crime prevention}

Brunelleschi "did not like to put his ideas to paper, probably because he was afraid that these could be stolen". ${ }^{41}$ To an extent, his inability to protect his inventions from appropriation, stalled the development of engineering technology. According to Innocenzi,

The construction machines for the Cupola were truly revolutionary for the time and introduced several innovative ideas, such as the lifting gears and speed gears that made the operation easier and faster. The sad truth, however, is that, following their innovative use in the construction of Brunelleschi's Cupola, they were quickly forgotten, at least from a practical point of view, and had no further impact in advancing construction technology. Brunelleschi's use of such machines to aid construction remained a unique case, and, with the exception of the architects and engineers, discussed above who studied and transmitted the memory of his innovative machines, we do not have evidence that any others tried to take advantage of his work in a practical sense. It would be necessary to wait for the beginning of the industrial revolution in the late eighteenth century to see the development of such advanced construction devices again. ${ }^{42}$

\section{1 'Stealing' patents}

\footnotetext{
$40 \quad$ See Patents Regulations 2014 (LI 2014/275), reg 28 "Preparation of drawings". See also Patent Cooperation Treaty Rules r 11.13(c)-(e), (g)-(h), (l). Innocenzi, above n 16, at 43 . 
Since a patent is personal property, ${ }^{43}$ it might be capable of being stolen ${ }^{44}$ but, in practice, patents are infringed, leading to civil remedies. ${ }^{45}$ However, usurping the opportunity to register a patent can constitute theft. For example, if A takes confidential information from an inventor B, and, without B's consent, applies for patent registration in their own name, and with the intention of depriving B of the right to register a patent, A can be charged with theft. ${ }^{46}$

\subsection{How drawings can prevent theft?}

These drawings are instrumental in proving inventiveness for patent registration purposes, and therefore the creation of property rights. They also constitute evidence that can contribute to preventing appropriation of that property. Furthermore, they can be instrumental in proving infringement of copyright or registered designs.

\section{Conclusion}

This working paper has sought to establish the foundations for a more substantial study that will delve deeper into the development of perspectival drawings, their historical use in proving and protecting intellectual property claims, and effectively preventing appropriation of

\footnotetext{
43 See Patents Act 2013, s 17(1).

$44 \quad$ After the Supreme Court decision in Dixon $v R$ [2015] NZSC 147, digital files may be considered stealable property.

Crimes Act 1961, s 230 “Taking, obtaining, or copying trade secrets” provides:
}

(1) Every one is liable to imprisonment for a term not exceeding 5 years who, with intent to obtain any pecuniary advantage or to cause loss to any other person,-

(a) dishonestly and without claim of right, takes, obtains, or copies any document or any model or other depiction of any thing or process containing or embodying any trade secret, knowing that it contains or embodies a trade secret; or (b) dishonestly and without claim of right, takes or obtains any copy of any document or any model or other depiction of any thing or process containing or embodying any trade secret, knowing that it contains or embodies a trade secret.

(2) For the purposes of this section, trade secret means any information that-

(a) is, or has the potential to be, used industrially or commercially; and

(b) is not generally available in industrial or commercial use; and

(c) has economic value or potential economic value to the possessor of the information; and

(d) is the subject of all reasonable efforts to preserve its secrecy. 
property rights, and, perhaps, even preventing crime. So far, the role of Brunelleschi in finding a way to bring the central vanishing point of Euclidian geometry into a practical device for replicating the natural phenomenon of linear perspective. The critical role of drawings that can plausibly portray the round in the flat has been identified, for example, in architecture and patent applications. These basic points will be further developed in due course. 